American Journal of Applied Sciences 8 (7): 716-723, 2011

ISSN 1546-9239

(C) 2011 Science Publications

\title{
Analytical and Experimental Studies on the Thermal Efficiency of the Double-Pass Solar Air Collector with Finned Absorber
}

\author{
Ahmad Fudholi, Kamaruzzaman Sopian, Mohd Hafidz Ruslan, \\ Mohd. Yusof Othman and Muhammad Yahya \\ Solar Energy Research Institute, University Kebangsaan Malaysia, \\ 43600 UKM Bangi, Selangor Darul Ehsan, Malaysia
}

\begin{abstract}
Problem statement: The design of suitable air collectors is one of the most important factors controlling the economics of the solar drying. Air type collectors have two inherent disadvantages: Low thermal capacity of air and low absorber to air heat transfer coefficient. Different modifications are suggested and applied to improve the heat transfer coefficient between the absorber plate and air. These modifications include the use of extended heat transfer area, such as finned absorber. Approach: The efficiency of the solar collector has been examined by changing the solar radiation and the mass flow rate. An analytical and experimental study to investigate the effect of mass flow rate and solar radiation on thermal efficiency were conducted. The theoretical solution procedure of the energy equations uses a matrix inversion method and making some algebraic rearrangements. Results: The average error on calculating thermal efficiency was about 7\%. The optimum efficiency, about $70 \%$ lies between the mass flow rates $0.07-0.08 \mathrm{~kg} \mathrm{sec}^{-1}$. The thermal efficiencies increase with flow rate and it increase about $30 \%$ at mass flow rate of $0.04-0.08 \mathrm{~kg} \mathrm{sec}^{-1}$. Conclusion: The efficiency is increased proportional to mass flow rate and solar radiation and the efficiency of the collector is strongly dependent on the flow rate.
\end{abstract}

Key words: Double-pass solar air collector, finned absorber, thermal efficiency

\section{INTRODUCTION}

Depleting of fossil and gas reserves, combined with the growing concerns of global warming, has necessitated an urgent search for alternative energy sources to cater to the present day demands. An alternative energy resource such as solar energy is becoming increasingly attractive. Solar energy is a permanent and environmentally friendly source of renewable energy. The use of non-renewable fuels, such as fossil fuel has many side effects. Their combustion products produce pollution, acid rain and global warning.

Solar drying system is one of the most attractive and promising applications of solar energy systems in tropical and subtropical countries. The technical development of solar drying systems can proceed in two directions. Firstly, simple, low power, short life and comparatively low efficiency-drying system. Secondly, high efficiency, high power, long life expensive drying system (Fudholi et al., 2010).
One of the most important components of a solar energy system is the solar collector. It is can be used for many applications in drying of agricultural products, space heating, water heating, solar desalination. Improving their performance is essential for commercial acceptance of their use in such applications. It is important to note that the most crucial parameter of solar air collectors design is the forced convective heat transfer coefficient between the air and absorber plate (Fudholi et al., 2008).

The design of suitable air collectors is one of the most important factors controlling the economics of the solar drying. To date, flat plate solar collectors are widely used. Air may be allowed to flow above, below or both sides of the absorber plate. Air flow under the absorber plate reduces the heat losses through the glazing. Major heat losses from the collector occur at the front cover, because the front face must be exposed to atmosphere, whereas the sides and the back of the collector can be insulated adequately. Air type collectors have two inherent disadvantages: low thermal

Corresponding Author: A. Fudholi, Solar Energy Research Institute, University Kebangsaan, 43600 UKM Bangi, Selangor Darul Ehsan, Malaysia 
capacity of air and low absorber to air heat transfer coefficient. Different modifications are suggested and applied to improve the heat transfer coefficient between the absorber plate and air (Supranto et al., 2009). These modifications include the used an extended heat transfer area, such as absorber with fins attached, Vcorrugated collector and collector with porous media.

Sopian et al. (2009) studied on the thermal efficiency with and without porous media of the double-pass solar air collector for various operation conditions. They concluded that typical thermal efficiency of the double-pass solar air collector with porous media is about $60-70 \%$. Pradhapraj et al. (2010) reviewed on porous and non porous flat plate air collector with mirror enclosure. They discussed the performances of porous and non-porous absorber plates, the possible methods of finding out air leakages and the methodology adopted for the performance and efficiency calculations.

Various designs of solar collectors have been the subject of many theoretical and experimental investigations. Helal et al. (2010) studied energetic performances of an integrated collector storage solar water heater. The systems shows little cost, simplicity and simpler to be installed on the building roof. Prasad et al. (2010) studied experiment analysis of flat plate collector and comparison of performance with tracking collector. Dammak et al. (2010) optimized hybrid of flat plate collector with a bubble pump for absorptiondiffusion cooling systems. Reda (2010) studied the stability of luminescent solar collector prepared by solgel spin coating method using Ponceau 2R.

In the present study, the main concern is to study theoretically and experimentally on the thermal efficiency of the double-pass solar air collector with finned absorber.

\section{MATERIALS AND METHODS}

Figure 1 shows the cross section of the double-pas collector with the finned absorber. The collector consists of the glass cover, the insulated container and the black painted aluminum absorber. The size of the collector is $1.2 \mathrm{~m}$ wide and $2.4 \mathrm{~m}$ long. In this type of collector, the air initially enters through the first channel formed by the glass covering the absorber plate and then through the second channel formed by the back plate and the finned absorber. The size of the fins is $6 \mathrm{~cm}$ wide and $20 \mathrm{~cm}$ long. The fins have area of $1.512 \mathrm{~m}^{2}$.

Figure 2-3 show the schematic of the indoor testing facility and the experimental setup of the double- pass solar collector. The simulator uses 45 halogen lamps, each with rated power of $500 \mathrm{~W}$.

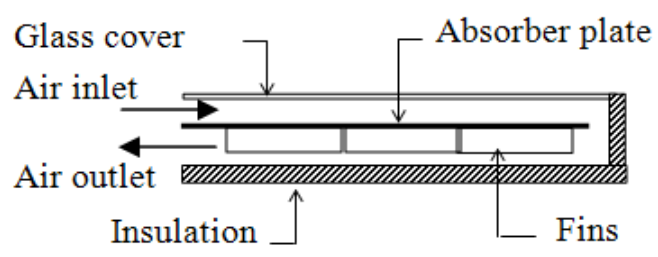

(a)

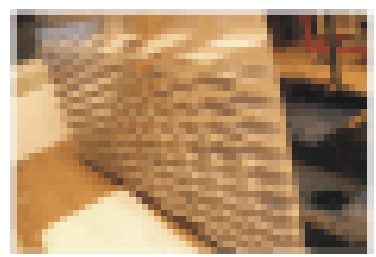

(b)

Fig. 1: (a) The schematic of a double-pass solar collector with finned absorber and (b) Photograph of the finned absorber

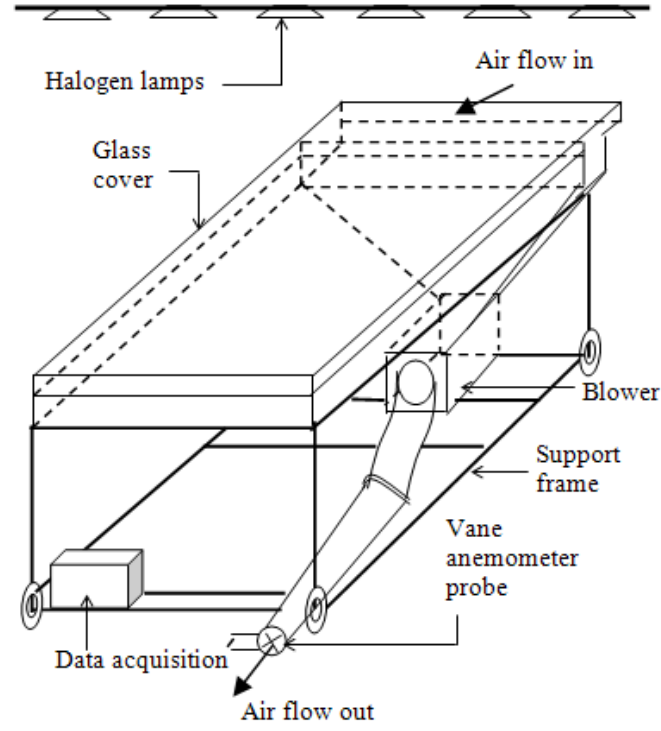

Fig. 2: Experimental setup of solar collector

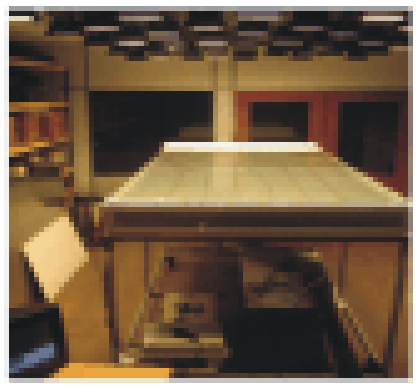

Fig. 3: Photograph of test facility of solar air collector 


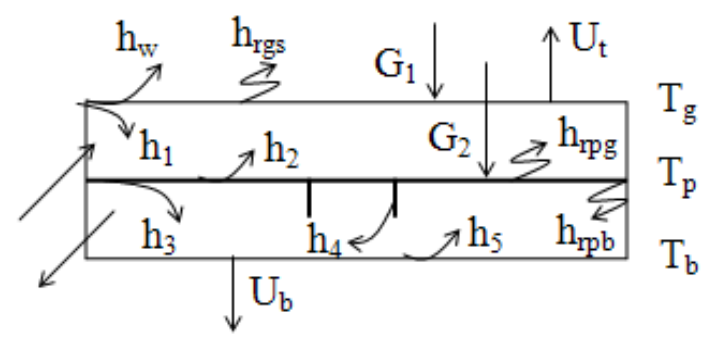

Fig. 4: Schematic of heat transfer coefficients in double-pass solar collector

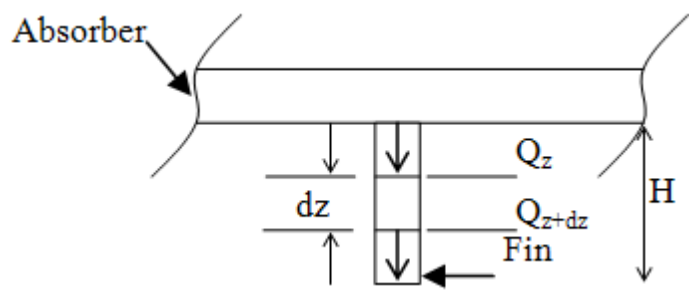

Fig. 5: Schematic of energy balance for each element of the fin

The maximum average radiation of $788 \mathrm{~W} / \mathrm{m}^{2}$ can be reached. Dimmers are used to control the amount of radiation that the test collector received. A Data acquisition recorder is used to record the required parameters such as the temperatures (inlet, outlet, absorber, glass cover and ambient) and intensity of the solar simulator. A type-T thermocouple is used in this experiment.

A pyranometer is used to measure the solar intensities. A vane anemometer probe is used to measure linear velocity of air flow. The lighting control of the simulator has been adjusted to obtain the required radiation levels. The solar collector has been operated at varying air mass flow rate and radiation conditions.

Theoretical analysis: Figure 4 shows the various heat transfer coefficients of double-pass solar collectors with finned absorbers. Figure 5 shows energy balance for each element of the fin with a height (dz).

To simplify the analysis, the following assumptions have been made (a) performance is steady state (b) all convection heat transfer coefficients in channels and flowing air are equal and constant (3) thermal conductivity of fin and absorber are constant and (4) the useful heat gain to the air is uniform along the length of the collector.

The steady state energy balance equations from Fig. 4 can be written as follow.

$\mathrm{T}_{\mathrm{g}}:$
$\mathrm{U}_{\mathrm{t}}\left(\mathrm{T}_{\mathrm{g}}-\mathrm{T}_{\mathrm{a}}\right)+\mathrm{h}_{1}\left(\mathrm{~T}_{\mathrm{g}}-\mathrm{T}_{\mathrm{f} 1}\right)=\mathrm{h}_{\mathrm{rpg}}\left(\mathrm{T}_{\mathrm{p}}-\mathrm{T}_{\mathrm{g}}\right)+\alpha_{\mathrm{g}} \mathrm{I}$

$\mathrm{T}_{\mathrm{f} 1}$ :

$\mathrm{Q}_{1}=\mathrm{h}_{1}\left(\mathrm{~T}_{\mathrm{g}}-\mathrm{T}_{\mathrm{f} 1}\right)+\mathrm{h}_{2}\left(\mathrm{~T}_{\mathrm{p}}-\mathrm{T}_{\mathrm{f} 1}\right)$

$\mathrm{T}_{\mathrm{p}}$ :

$\mathrm{h}_{\mathrm{rpg}}\left(\mathrm{T}_{\mathrm{p}}-\mathrm{T}_{\mathrm{g}}\right)+\mathrm{h}_{2}\left(\mathrm{~T}_{\mathrm{p}}-\mathrm{T}_{\mathrm{f} 1}\right)+\mathrm{h}_{\mathrm{rpg}}\left(\mathrm{T}_{\mathrm{p}}-\mathrm{T}_{\mathrm{g}}\right)$

$+\mathrm{h}_{3}\left(\mathrm{~T}_{\mathrm{p}}-\mathrm{T}_{\mathrm{f} 2}\right)+\frac{\mathrm{N}}{\mathrm{A}_{\mathrm{f}}} \mathrm{Q}_{\mathrm{fn}}=\alpha_{\mathrm{p}} \tau_{\mathrm{g}} \mathrm{I}$

$\mathrm{T}_{\mathrm{f} 2}$ :

$\mathrm{Q}_{2}=\mathrm{h}_{3}\left(\mathrm{~T}_{\mathrm{p}}-\mathrm{T}_{\mathrm{f} 2}\right)+\mathrm{h}_{5}\left(\mathrm{~T}_{\mathrm{b}}-\mathrm{T}_{\mathrm{f} 2}\right)+\frac{\mathrm{N}}{\mathrm{A}_{\mathrm{f}}} \mathrm{Q}_{\mathrm{fn}}$

$\mathrm{T}_{\mathrm{b}}$ :

$\mathrm{h}_{\mathrm{rpb}}\left(\mathrm{T}_{\mathrm{p}}-\mathrm{T}_{\mathrm{b}}\right)=\mathrm{h}_{5}\left(\mathrm{~T}_{\mathrm{b}}-\mathrm{T}_{\mathrm{f} 2}\right)+\mathrm{U}_{\mathrm{b}}\left(\mathrm{T}_{\mathrm{b}}-\mathrm{T}_{\mathrm{a}}\right)$

Where:

$\mathrm{Q}_{1}=2 \dot{\mathrm{m} C}\left(\mathrm{~T}_{\mathrm{f} 1}-\mathrm{T}_{\mathrm{f} 1 \mathrm{i}}\right) / \mathrm{wL}$

$\mathrm{Q}_{2}=2 \dot{\mathrm{m} C}\left(\mathrm{~T}_{\mathrm{f} 2}-\mathrm{T}_{\mathrm{f} 2, \mathrm{i}}\right) / \mathrm{wL}$

By making an energy balance for a differential element of a fin with a height (dz) shown in Fig. 5 can be expressed as:

$\mathrm{Q}_{\mathrm{z}}=\mathrm{Q}_{\mathrm{z}+\mathrm{dz}}+\mathrm{h}_{\mathrm{fn}}(2 \mathrm{ldz})\left(\mathrm{T}_{\mathrm{fn}}-\mathrm{T}_{\mathrm{f} 1}\right)$

Where:

$\mathrm{Q}_{\mathrm{z}}=-\mathrm{kA}_{\mathrm{sf}} \frac{\mathrm{dT}_{\mathrm{fn}}}{\mathrm{dz}}$

$\mathrm{Q}_{\mathrm{z}+\mathrm{dz}}=-\mathrm{kA}_{\mathrm{sf}}\left(\frac{\mathrm{dT}_{\mathrm{fin}}}{\mathrm{dz}}\right)_{\mathrm{z}+\mathrm{dz}}=-\mathrm{kA}_{\mathrm{sf}}\left(\frac{\mathrm{dT}_{\mathrm{fn}}}{\mathrm{dz}}+\frac{\mathrm{d}^{2} \mathrm{~T}_{\mathrm{fin}}}{\mathrm{dz}^{2}} \mathrm{dz}\right)$

Substituting Eq. 9 and 10 in Eq. 8, we get:

$\frac{\mathrm{d}^{2} \mathrm{~T}_{\mathrm{ff} 1}}{\mathrm{dz}^{2}}-\frac{2 \mathrm{~h}_{\mathrm{fn}} 1}{\mathrm{k}_{\mathrm{p}} \mathrm{A}_{\mathrm{sf}}}\left(\mathrm{T}_{\mathrm{fn} 1}-\mathrm{T}_{\mathrm{f} 1}\right)=0$

For simplicity, let: 
$\theta_{1}=\mathrm{T}_{\mathrm{fn}}-\mathrm{T}_{\mathrm{f} 1}$

$\mathrm{M}^{2}=\frac{2 \mathrm{~h}_{\mathrm{fn}} 1}{\mathrm{k}_{\mathrm{p}} \mathrm{A}_{\mathrm{sf}}}$

Then Eq. 11 becomes:

$\frac{\mathrm{d}^{2} \theta_{1}}{\mathrm{dz}^{2}}-\mathrm{M}^{2} \theta_{1}=0$

It is a linear homogeneous, second order differential equation. The general solution for Eq. 14 is:

$\theta_{1}=\lambda_{1} \cosh \mathrm{M}(\mathrm{H}-\mathrm{z})+\lambda_{2} \sinh \mathrm{M}(\mathrm{H}-\mathrm{z})$

where, $\lambda_{1}$ and $\lambda_{2}$ are constants and depend on the boundary conditions:

for $\mathrm{z}=0, \mathrm{~T}_{\mathrm{p}}-\mathrm{T}_{\mathrm{f} 1}=\theta_{0}$

forz $=H, d \theta_{1} / d z=0$

from boundary conditions, Eq. 15 can be written as:

$\theta_{1}=\frac{\theta_{0}}{\cosh M H} \cosh \mathrm{M}(\mathrm{H}-\mathrm{z})$

The fin heat transfer rate from the fin base:

$\mathrm{Q}_{\mathrm{fn}}=\mathrm{Q}_{\mathrm{z}=0}=-\mathrm{kA}_{\mathrm{sf}}\left(\frac{\mathrm{dT}_{\mathrm{fn}}}{\mathrm{dz}}\right)_{\mathrm{z}=0}$

$=\left(2 \mathrm{k}_{\mathrm{p}} \mathrm{A}_{\mathrm{sf}} \mathrm{lh}_{\mathrm{fn}}\right)^{1 / 2}\left(\mathrm{~T}_{\mathrm{p}}-\mathrm{T}_{\mathrm{f} 1}\right) \tanh \mathrm{MH}$

Where:

$\mathrm{T}_{\mathrm{fn}}=$ Fin temperature in the lower channel

$\mathrm{h}_{\mathrm{fn}}=$ Convective heat transfer coefficient between the fin and air in the lower channel

The major design parameters are as follows: $\mathrm{L}=$ $2.4 \mathrm{~m}, \mathrm{w}=1.2 \mathrm{~m}, \alpha_{\mathrm{p}}=0.95, \alpha_{\mathrm{g}}=0.06, \varepsilon_{\mathrm{p}}=0.95, \varepsilon_{\mathrm{g}}=$ $0.8, \tau_{\mathrm{g}}=0.9, \mathrm{U}_{\mathrm{b}}=1 \mathrm{~W} \mathrm{~m} \mathrm{~W}^{-2} \mathrm{~K}, \mathrm{k}_{\mathrm{p}}=211 \mathrm{~W} \mathrm{mK}^{-1}, \mathrm{~T}_{\mathrm{a}}=300$ $\mathrm{K}, \mathrm{T}_{\mathrm{i}}=303 \mathrm{~K}, \mathrm{I}=700 \mathrm{~W} \mathrm{~m}^{-2}$.

The mean air and wall temperatures of the first section are initially guessed and specified. In the study except that of the absorber which was set to a temperature $30^{\circ} \mathrm{C}$ above that of the ambient temperature.

Theoretical solution procedure: The theoretical model assumes that for a short collector, the temperatures of the wall surrounding the airflow are uniform and temperatures of the airflow vary linearly along the collector. For the short collectors, the mean air temperature is then equal to the arithmetic mean (Choundhury et al., 1995).

Where:

$T_{f 1}=\left(T_{f 1, o}+T_{i}\right) / 2$

$\mathrm{T}_{\mathrm{f} 2}=\left(\mathrm{T}_{\mathrm{f} 2, \mathrm{o}}+\mathrm{T}_{\mathrm{f} 1, \mathrm{o}}\right) / 2$

In general, the above Eq. 1-5 can be presented in a $5 \times 5$ matrix form. The above matrices may be displayed as (Fudholi et al., 2011)

$[\mathrm{A}][\mathrm{T}]=[\mathrm{B}]$

$\left[\begin{array}{ccccc}\mathrm{S}_{6} & -\mathrm{h}_{1} & -\mathrm{h}_{\mathrm{rpg}} & 0 & 0 \\ \mathrm{~h}_{1} & \mathrm{~S}_{7} & \mathrm{~S}_{8} & 0 & 0 \\ -\mathrm{h}_{\mathrm{rpg}} & \mathrm{S}_{9} & \mathrm{~S}_{10} & -\mathrm{h}_{4} & -\mathrm{h}_{\mathrm{rpb}} \\ 0 & 4 \dot{\mathrm{mC}} / \mathrm{wL} & \mathrm{h}_{4} & \mathrm{~S}_{11} & \mathrm{~h}_{5} \\ 0 & 0 & \mathrm{~h}_{\mathrm{rpb}} & \mathrm{h}_{5} & \mathrm{~S}_{12}\end{array}\right]\left[\begin{array}{c}\mathrm{T}_{\mathrm{g}} \\ \mathrm{T}_{\mathrm{f} 1} \\ \mathrm{~T}_{\mathrm{p}} \\ \mathrm{T}_{\mathrm{f} 2} \\ \mathrm{~T}_{\mathrm{b}}\end{array}\right]=\left[\begin{array}{l}\mathrm{S}_{1} \\ \mathrm{~S}_{2} \\ \mathrm{~S}_{3} \\ \mathrm{~S}_{4} \\ \mathrm{~S}_{5}\end{array}\right]$

Where:

$\mathrm{S}_{1}=\mathrm{U}_{\mathrm{t}} \mathrm{T}_{\mathrm{a}}+\alpha_{\mathrm{g}} \mathrm{I}$

$\mathrm{S}_{2}=-(2 \dot{\mathrm{mC}} / \mathrm{wL}) \mathrm{T}_{\mathrm{i}}$

$\mathrm{S}_{3}=\alpha_{\mathrm{p}} \tau_{\mathrm{g}} \mathrm{I}$

$\mathrm{S}_{4}=-\mathrm{S}_{2}$

$\mathrm{S}_{5}=-\mathrm{T}_{\mathrm{a}} \mathrm{U}_{\mathrm{b}}$

$\mathrm{S}_{6}=\mathrm{h}_{1}+\mathrm{h}_{\mathrm{rpg}}+\mathrm{U}_{\mathrm{t}}$

$\mathrm{S}_{7}=-\left[\mathrm{h}_{1}+\mathrm{h}_{2}+(2 \dot{\mathrm{mC}} / \mathrm{wL})\right]$

$\mathrm{S}_{8}=\mathrm{h}_{2}+\mathrm{h}_{3}+\mathrm{h}_{\mathrm{rpg}}+\mathrm{h}_{\mathrm{rpb}}+\frac{\mathrm{N}}{\mathrm{A}_{\mathrm{f}}}\left(2 \mathrm{kA}_{\mathrm{sf}} \mathrm{Lh}_{4}\right)^{1 / 2} \tanh \mathrm{MH}$

$\mathrm{S}_{9}=-\left[\mathrm{h}_{3}+\frac{\mathrm{N}}{\mathrm{A}_{\mathrm{f}}}\left(2 \mathrm{kA}_{\mathrm{sf}} \mathrm{Lh}_{4}\right)^{1 / 2} \tanh \mathrm{MH}\right]$

$\mathrm{S}_{10}=-\mathrm{S}_{9}$ 


$$
\begin{aligned}
& \mathrm{S}_{11}=-\left[\begin{array}{l}
\mathrm{h}_{3}+\mathrm{h}_{5}+(2 \mathrm{mC} / \mathrm{wL}) \\
+\frac{\mathrm{N}}{\mathrm{A}_{\mathrm{f}}}\left(2 \mathrm{kA}_{\mathrm{sf}} \mathrm{Lh}_{4}\right)^{1 / 2} \tanh \mathrm{MH}
\end{array}\right] \\
& \mathrm{S}_{12}=-\left(\mathrm{h}_{5}+\mathrm{h}_{\mathrm{rpb}}+\mathrm{U}_{\mathrm{b}}\right) \\
& \mathrm{M}=\left(\frac{2 \mathrm{Lh}_{4}}{\mathrm{k}_{\mathrm{p}} \mathrm{A}_{\mathrm{sf}}}\right)^{1 / 2}
\end{aligned}
$$

Incorporating these relations in Eq. 2 and 4 and making some algebraic rearrangements, the mean temperature vector may be determined with Excel by matrix inversion form.

$$
[\mathrm{T}]=[\mathrm{A}]^{-1}[\mathrm{~B}]
$$

The newly computed temperatures are then compared with the previously assumed ones and computed is repeated until all consecutive mean temperatures differ by less than $0.01{ }^{\circ} \mathrm{C}$. In the present case, a sufficient convergence for $T_{g}, T_{f 1}, T_{p}, T_{f 2}$ and $T_{b}$ are achieves in 4-6 iterations.

\section{RESULTS AND DISCUSSION}

The physical properties of air are assumed to vary linearly with temperature $\left({ }^{\circ} \mathrm{C}\right)$ (Alfegi et al., 2009) specific heat:

$\mathrm{C}_{\mathrm{p}}=1.0057+0.000066(\mathrm{~T}-27)$

density:

$\rho=1.1774-0.00359(\mathrm{~T}-27)$

thermal conductivity:

$$
\mathrm{k}=0.02624+0.0000758(\mathrm{~T}-27)
$$

viscosity:

$$
\mu=\left[1.983+0.00184(\mathrm{~T}-27) 10^{-5}\right]
$$

The useful gain by the solar collector to solar radiation with values of fluid inlet and outlet temperature and the fluid mass flow rate is given as follows:

$$
\mathrm{Q}_{\mathrm{u}}=\dot{\mathrm{m} C}\left(\mathrm{~T}_{\mathrm{o}}-\mathrm{T}_{\mathrm{i}}\right)
$$

where, $\mathrm{C}$ is the specific heat of the fluid. The efficiency of the collector is given by:

$$
\begin{aligned}
& \eta=\frac{Q_{u}}{A_{f} I}=\frac{\dot{m} C\left(T_{o}-T_{i}\right)}{A_{f} I} \\
& \eta=F_{o}(\tau \alpha)-F_{o} U_{L} \frac{\left(T_{o}-T_{a}\right)}{S}
\end{aligned}
$$

Where:

$\mathrm{A}_{\mathrm{f}}=$ The area of collector

$\mathrm{I}=$ The solar radiation incident on the collector

$\mathrm{F}_{\mathrm{o}}=$ Heat removal factor referred to outlet temperature of solar collector

$\mathrm{U}_{\mathrm{L}}=$ Collector total loss coefficient

The heat transfer coefficients are computed accordingly, such as:

$\mathrm{h}_{\mathrm{w}}=2.8+3.3 \mathrm{~V}$

where, $h_{w}$ is the convection heat transfer coefficient due to wind and $\mathrm{V}$ is the wind velocity:

$$
\mathrm{h}_{\mathrm{rpg}}=\frac{\sigma\left(\mathrm{T}_{\mathrm{p}}^{2}+\mathrm{T}_{\mathrm{g}}^{2}\right)\left(\mathrm{T}_{\mathrm{p}}+\mathrm{T}_{\mathrm{g}}\right)}{\frac{1}{\varepsilon_{\mathrm{p}}}+\frac{1}{\varepsilon_{\mathrm{g}}}-1}
$$

$\mathrm{h}_{\mathrm{rgs}}=\frac{\sigma \varepsilon_{\mathrm{g}}\left(\mathrm{T}_{\mathrm{g}}+\mathrm{T}_{\mathrm{s}}\right)\left(\mathrm{T}_{\mathrm{g}}^{2}+\mathrm{T}_{\mathrm{s}}^{2}\right)\left(\mathrm{T}_{\mathrm{g}}-\mathrm{T}_{\mathrm{s}}\right)}{\mathrm{T}_{\mathrm{g}}-\mathrm{T}_{\mathrm{a}}}$

there $T_{s}$ is the sky temperature:

$\mathrm{T}_{\mathrm{s}}=0.0552\left(\mathrm{~T}_{\mathrm{a}}\right)^{1.5}$

$\mathrm{U}_{\mathrm{t}}=\left(\frac{1}{\mathrm{~h}_{\mathrm{w}}+\mathrm{h}_{\mathrm{rgs}}}\right)^{-1}$

The convective heat transfer coefficients are calculated using following relations:

$\mathrm{h}=\frac{\mathrm{k}}{\mathrm{D}_{\mathrm{h}}} \mathrm{Nu}$

Where:

$\mathrm{Nu}=$ Nusselt number

$D_{h}=$ The equivalence diameter of the channel

Nusselt number for laminar flow region $(\operatorname{Re}<2300)$, transition flow region $(2300<\operatorname{Re}<6000)$ and 
turbulent flow region respectively are (Basria et al., 2007; Fudholi et al., 2011):

$$
\begin{aligned}
& \mathrm{Nu}=5.4+\frac{0.00190\left[\operatorname{Re} \operatorname{Pr}\left(\frac{\mathrm{D}_{\mathrm{h}}}{\mathrm{L}}\right)\right]^{1.71}}{1+0.00563\left[\operatorname{Re} \operatorname{Pr}\left(\frac{\mathrm{D}_{\mathrm{h}}}{\mathrm{L}}\right)\right]^{1.17}} \\
& \mathrm{Nu}=0.116\left(\operatorname{Re}^{2 / 3}-125\right) \operatorname{Pr}^{1 / 3}\left[1+\left(\frac{\mathrm{D}_{\mathrm{h}}}{\mathrm{L}}\right)^{2 / 3}\right]\left(\frac{\mu}{\mu_{\mathrm{w}}}\right)^{0.14}
\end{aligned}
$$

$\mathrm{Nu}=0.018 \operatorname{Re}^{0.8} \operatorname{Pr}^{0.4}$

Where:

$\operatorname{Pr}=$ Prandtl

$\operatorname{Re}=$ The Reynolds number:

$$
\begin{aligned}
& \operatorname{Re}=\frac{\dot{\mathrm{m}} D_{h}}{A_{f} \mu} \\
& D_{h}=\frac{4 w d}{2(w+d)}
\end{aligned}
$$

Figure 6-8 shows the effect mass of flow rate on the efficiency of the double-pass solar air collector with finned absorber. The efficiency of the collector is strongly dependent on the flow rate.

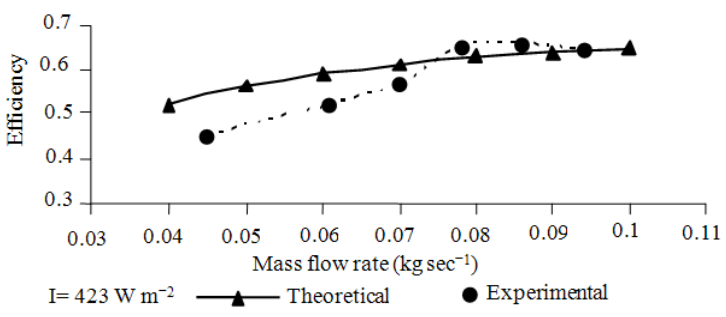

Fig. 6: Variation of efficiency with mass flow rate for $\mathrm{I}=423 \mathrm{~W} \mathrm{~m}^{-2}$

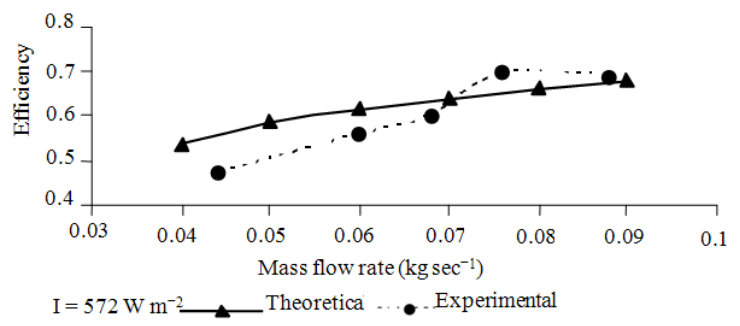

Fig. 7: Variation of efficiency with mass flow rate for I $=572 \mathrm{~W} \mathrm{~m}^{-2}$
The collector efficiencies increase with flow rate, efficiency increase is about $30 \%$ at mass flow rate of $0.04-0.08 \mathrm{~kg} \mathrm{sec}^{-1}$. The optimum efficiency is about $70 \%$ lies between the mass flow rates $0.07-0.08 \mathrm{~kg}$ $\sec ^{-1}$.

To determine the physical characteristics of the collector, one represents effectiveness with efficiency curve, i.e. efficiency versus the reduced temperature parameters $\left(T_{0}-T_{a}\right) / S$ in Fig. 9-11. As seen in the figure shows the efficiency curve decrease with increase of the reduced temperature parameters. The curve obtained is a straight line. It will results where the slope is equal to $\mathrm{F}_{\mathrm{o}} \mathrm{U}_{\mathrm{L}}$ and the $\mathrm{y}$-intercept is equal to $\mathrm{F}_{\mathrm{o}}(\tau \alpha)$. The respective efficiency equation and the physical characteristic of the collector are presented in Table 1-2.

The model is validated by comparing with the experimental. It can be clearly seen from figures or table that the error on calculating the thermal efficiency are about $6.47 \%, 6.84 \%$ and $6.23 \%$ for $\mathrm{I}=423 \mathrm{~W} \mathrm{~m}^{-2}$, I $=572 \mathrm{~W} \mathrm{~m}^{-2}$ and $\mathrm{I}=788 \mathrm{~W} \mathrm{~m}^{-2}$, respectively. The model gives fair prediction with an average error of $6.5 \%$. This may be due to error in the initial conditions, as well as the thermal conductivity of the fin material.

The effect of solar radiation on the efficiency of experimental study is shown in Fig. 15.

Table 1: Efficiency, loss factor and efficiency equation of doublepass solar air collector of theoretical study (from Fig. 9, 11 and 13)

\begin{tabular}{lllll}
\hline $\mathrm{S}\left(\mathrm{W} \mathrm{m}^{-2}\right)$ & $\mathrm{F}_{\mathrm{o}}(\tau \alpha)$ & $\mathrm{F}_{\mathrm{o}} \mathrm{U}_{\mathrm{L}}$ & Efficiency equations & $\mathrm{R}^{2}$ \\
\hline 423 & 0.67 & 2.3 & $\mathrm{y}=-2.3 \mathrm{x}+67.4$ & 0.95 \\
572 & 0.71 & 2.6 & $\mathrm{y}=-2.6 \mathrm{x}+70.9$ & 0.95 \\
788 & 0.74 & 2.9 & $\mathrm{y}=-2.9 \mathrm{x}+73.6$ & 0.96 \\
\hline
\end{tabular}

\begin{tabular}{|c|c|c|c|c|}
\hline $\mathrm{S}\left(\mathrm{W} \mathrm{m}^{-2}\right)$ & $\mathrm{F}_{\mathrm{o}}(\tau \alpha)$ & $\mathrm{F}_{\mathrm{o}} \mathrm{U}_{\mathrm{L}}$ & Efficiency equations & $\mathrm{R}^{2}$ \\
\hline 423 & 0.73 & 4.1 & $y=-4.1 x+72.7$ & 0.85 \\
\hline 572 & 0.78 & 5.8 & $y=-5.8 x+77.8$ & 0.95 \\
\hline 788 & 0.84 & 6.9 & $y=-6.9 x+84.1$ & 0.97 \\
\hline
\end{tabular}

Table 2: Efficiency, loss factor and efficiency equation of doublepass solar air collector of experimental study (from Fig. 10, 12 and 14)

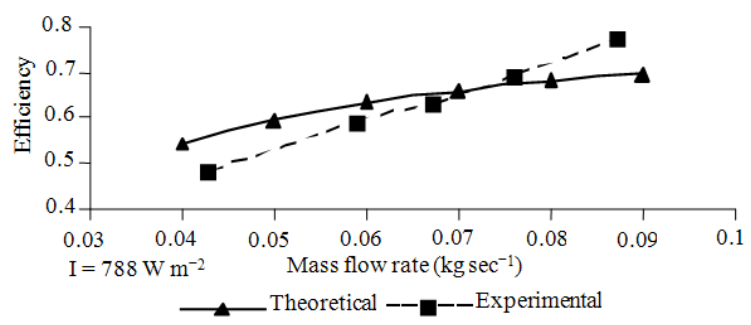

Fig. 8: Variation of efficiency with mass flow rate for I $=788 \mathrm{~W} \mathrm{~m}^{-2}$ 


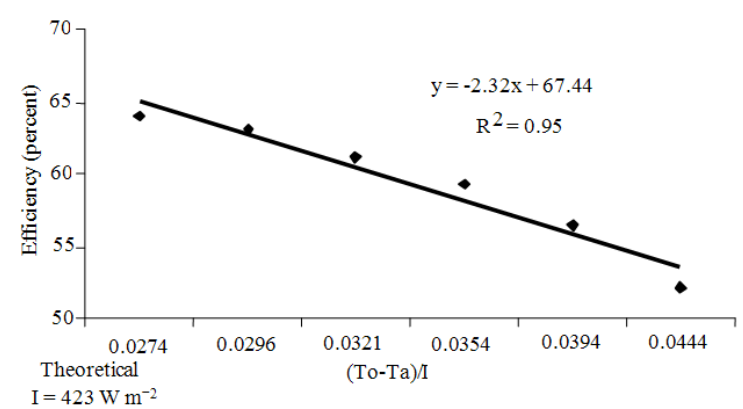

Fig. 9: Efficiency versus (To-Ta)/I of theoretical for I $=423 \mathrm{~W} \mathrm{~m}^{-2}$

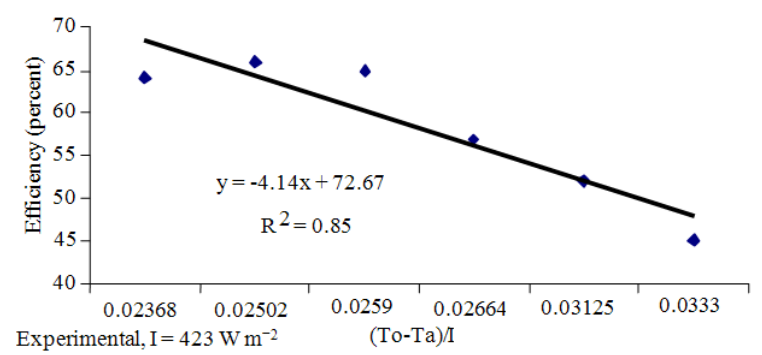

Fig. 10:Efficiency versus (To-Ta)/I of experimental for $\mathrm{I}=423 \mathrm{~W} \mathrm{~m}^{-2}$

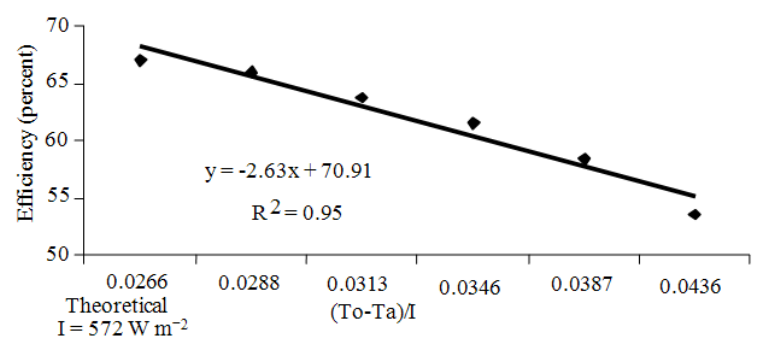

Fig. 11:Efficiency versus (To-Ta)/I of theoretical for I $=572 \mathrm{~W} \mathrm{~m}^{-2}$

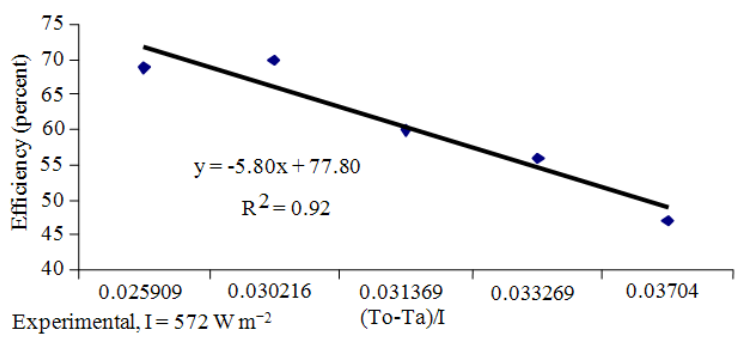

Fig. 12:Efficiency versus (To-Ta)/I of experimental for $\mathrm{I}=572 \mathrm{~W} \mathrm{~m}^{-2}$

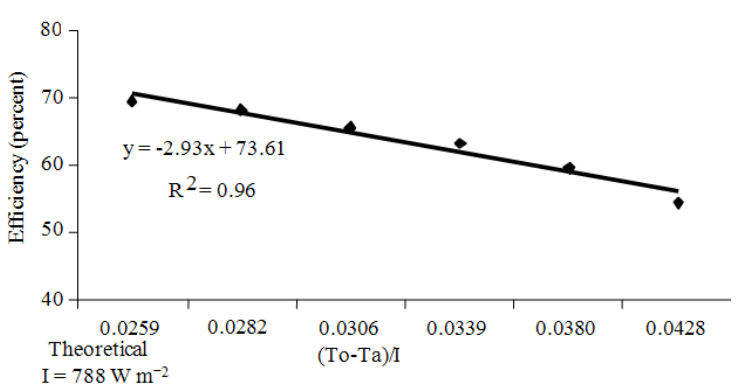

Fig. 13:Efficiency versus (To-Ta)/I of theoretical for I $=788 \mathrm{~W} \mathrm{~m}^{-2}$

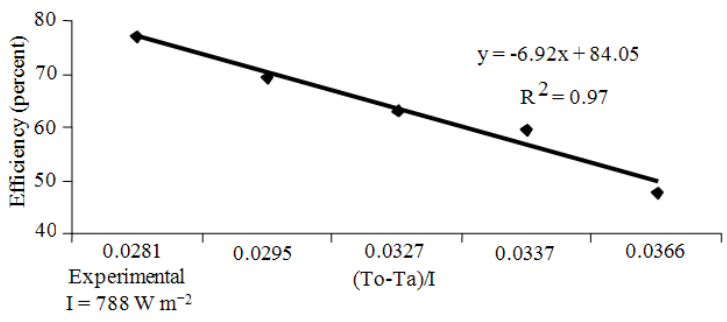

Fig. 14:Efficiency versus (To-Ta)/I of experimental for $\mathrm{I}=788 \mathrm{~W} \mathrm{~m}^{-2}$

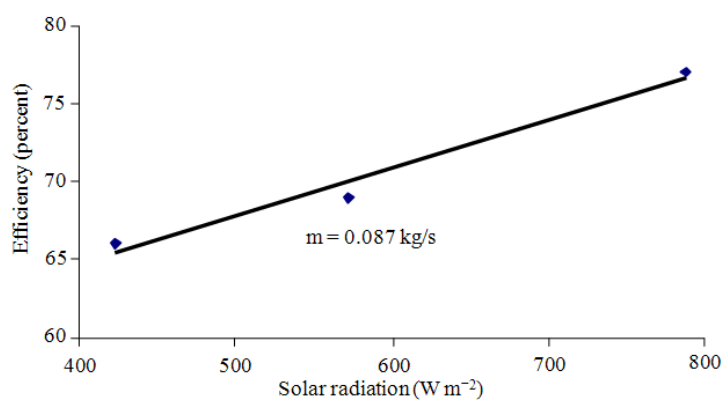

Fig. 15: The effect of solar radiation on efficiency

At the solar radiation at $423-788 \mathrm{~W} \mathrm{~m}^{-2}$ and mass flow rate $0.087 \mathrm{~kg} \mathrm{sec}^{-1}$ increase efficiency is about $11 \%$.

\section{CONCLUSION}

Performance curves of double-pass solar air collector with finned absorber in lower channel have been obtained. These include the effects of mass flow rate and solar radiation on efficiency of the solar collector. The efficiency of the collector is strongly dependent on the flow rate. It increases with flow rate. The optimum efficiency is about $70 \%$ lies between the mass flow rates $0.07-0.08 \mathrm{~kg} \mathrm{sec}^{-1}$. The average error 
on calculating the thermal efficiency is about $7 \%$. The efficiency is increased proportional to mass flow rate and solar radiation.

\section{REFERENCES}

Alfegi, E.M.A., K. Sopian, M.Y.H. Othman and B. Yatim, 2009. Mathematical Model of Double-pass Photovoltaic Thermal Air Collector with Fins. Am. J. Environm. Sci., 5: 592-598. DOI: 10.3844/ajessp.2009.592.598

Basria, A., A. Yousef, N.M. Adam, K. Sopian and A. Zaharim et al., 2007. Analysis of single and double passes v-grooves solar collector with and without porous media. Int. J. Energy Environ., 2: 109-114. http://www.naun.org/journals/energyenvironment/e e-20.pdf

Choundhury, C., P.M. Chauhan and H.P. Garg, 1995. Performance and cost analysis of two-pass solar air heater. Heat Recovery Syst. CHP., 15: 755-773. http://eprint.iitd.ac.in:8080/bitstream/2074/4651/ch oper95.pdf

Dammak, N., B. Chaouachi, S. Gabsi and M. Bourouis, 2010. Optimization of the geometrical parameters of a solar bubble pump for absorption-diffusion cooling systems. Am. J. Engineer. Applied Sci., 3: 693-698. DOI: 10.3844/ajeassp.2010.693.698

Fudholi, A., K. Sopian, M.H. Ruslan, M.A. Alghoul and M.Y. Sulaiman, 2010. Reviev of solar dryers for agricultural and marine products. Renew. Sustainable Energy Rev., 14: 1-30. DOI: 10.1016/J.RSER.2009.07.032

Fudholi, A., K. Sopian, M.Y. Othman, M.H. Ruslan and M.A. AlGhoul et al., 2008. Heat transfer correlation for the v-groove solar collector. Proceedings of the 8th WSEAS International Conference on Simulation, Modeling and Optimization, Sept. 23-25, Santander, Cantabria, Spain, $\quad$ pp: 177-182. http://www.wseas.us/elibrary/conferences/2008/spa in/smo/smo28.pdf
Fudholi, A., K. Sopian, M.H.Ruslan, M.Y. Othman and M. Yahya, 2011. Thermal efficiency of double pass solar collector with longitudinal fins Absorbers. Am. J. Applied Sci., 8: 254-260. ISSN: 154-9239

Helal, O., B. Chaouachi, S. Gabsi and C. Bouden, 2010. Energetic performances study of an integrated collector storage solar water heater. Am. J. Engineer. Applied Sci., 3: 152-158. DOI: 10.3844/ajeassp.2010.152.158

Pradhapraj, M., V. Velmurugan and $H$. Sivarathinamoorthy, 2010. Review on porous and nonporous flat plate air collector with mirror enclosure. Int. J. Eng. Sci. Technol., 2: 4013-4019. http: //www.ijest.info/docs/IJEST10-02-09-03.pdf

Reda, S.M., 2010. Photostability of ponceau 2r doped thin film sol-gel silica as luminescent solar collector. Energy Res. J., 1: 36-41. DOI: 10.3844/erjsp.2010.36.41

Sopian, K., M.A. Alghoul, E.M. Alfegi, M.Y. Sulaiman and E.A. Musa, 2009. Evaluation of thermal efficiency of double-pass solar pollector with porous-nonporous media. Renew. Energy, 34: 640645. http://www.ewp.rpi.edu/hartford/ changj2/EP/supp orting_matls/topics/doublepass_col.pdf

Supranto, M.H. Ruslan, M. Yahya, M.Y. Sulaiman and M.A. Ghoul et al., 2009. Some design aspects of the assisted solar drying system with double- pass finned solar collectors. Proceedings of the 3rd WSEAS International Conference on Renewable Energy Sources, July 1-3, University of La Laguna, Tenerife, Canary Islands, Spain, pp: 326-330. http://www.wseas.us/elibrary/conferences/2009/lalaguna/EPREWA/EPR EWA50.pdf 